\title{
Proteolytic truncation of human transthyretin linked to amyloidosis is mediated by a trypsin like enzyme: In vitro demonstration using model peptides
}

Mysa Saad $^{1 \dagger}$, Chunyu Lu ${ }^{1 \dagger}$, Charita Koya ${ }^{1}$ and Ajoy Basak ${ }^{1,2^{*}}$

*Correspondence: abasa2@uottawa.ca

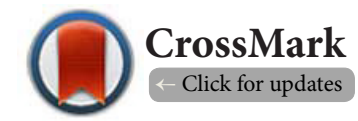

†These authors contributed equally to this work.

'Interdisciplinary School of Health Sciences, Faculty of Health Science, U Ottawa, 451 Smyth Road, Ottawa, ON K1 H 8M5, Canada.

${ }^{2}$ Chronic Disease Program, Ottawa Hospital Research Institute, U Ottawa, 725 Parkdale Ave, Ottawa, ON K1Y4E9, Canada.

\begin{abstract}
Background: A number of human conditions collectively known as amyloidosis were found to be associated with self-aggregation of a specific group of proteins. This fibril like protein aggregates deposit in different tissues including the central nervous system leading to amyloid polyneuropathies (AP), systemic senile amyloidosis (SSA), amyloidotic cardiomyopathy (AC) and carpal tunnel syndrome (CTS). The most common protein in this group is human transthyretin (hTTR). Similar to beta amyloid peptide of Alzheimer's Disease, hTTR forms amyloid type fibrils following its proteolytic cleavage at the C-(carboxy) terminus leading to aggregation. hTTR is normally present in blood where it binds with thyroid hormone thyroxine T4 and Retinol Binding Protein-Vitamin A complex and mediates their transport. It is also present in lower amount in cerebrospinal fluid as a major carrier of thyroxine hormone. Deposition of hTTR fibril aggregates is responsible for SSA usually observed in older population with age $>60$ years which is regulated by its mutant forms. The exact mechanism of this disorder is still unclear. Studies confirmed that C-terminally truncated hTTR undergoes rapid self-aggregation leading to amyloidosis. The site of this cleavage and the protease involved has not been fully characterized although it is proposed to be at $\mathrm{Lys}^{48} \downarrow \mathrm{Thr}^{49}$ residues.
\end{abstract}

Objective: The major goal of this study is to confirm that hTTR is cleaved by a trypsin like enzyme at the position indicated by vertical arrow Ala-Ser-Gly-Lys ${ }^{48} \downarrow \mathrm{Thr}^{49}-$ Ser-Glu-Ser and that this cleavage can be blocked by a trypsin-inhibitor.

Methods: A 20 mer peptide comprising the wild type sequence from residue (41-60) of hTTR was synthesized, purified by RP-HPLC and fully characterized by mass spectrometry. Three additional mutant peptides namely $\mathrm{Lys}^{48} / \mathrm{Ala}$, Ser ${ }^{52} /$ Pro and $\mathrm{Thr}^{49} / \mathrm{Ala}$ were also prepared. These mutant peptides were designed because of their pathological implications in SSA syndrome in varying degrees. All peptides were digested in vitro with trypsin under identical condition to examine and compare their cleavage efficiencies.

$\underline{\text { Results: }}$ Our results showed that while the control wild type peptide was fully cleaved at Lys ${ }^{48} \downarrow T h r^{49}$ by trypsin within an hour the corresponding Lys ${ }^{48} / \mathrm{Ala}$ mutant remained completely uncleaved under identical condition. In contrast the Ser ${ }^{52} /$ Pro and $\mathrm{Thr}^{49} /$ Ala mutant peptides were cleaved with varying efficiency. These results are consistent with those reported for the physiological full length hTTR proteins. Moreover the above cleavage can be blocked efficiently by a trypsin inhibitor (dimethyl formamide), reported for the first time in this study. Energy minimised 3D modeling study revealed that Lys ${ }^{48} / \mathrm{Ala}$ mutant exhibits a unique structural conformation compared to the corresponding wild type control peptide suggesting its potential role in regulating proteolytic cleavage. Overall our data confirmed the key role of a trypsin like enzyme in hTTR proteolysis leading to its truncation which facilitates its self-aggregation leading to amyloidosis. The study also highlighted a potential therapeutic strategy for hTTR associated amyloidosis by targeting this enzyme with specific inhibitors.

Keywords: Human transthyretin (hTTR), hTTR proteolysis, hTTR mutation, trypsin, reverse phase high performance layer chromatography (RP-HPLC), mass spectrum, trypsin inhibitor, trypsin activation, protein aggregation

(C) 2016 Basak et al; licensee Herbert Publications Ltd. This is an Open Access article distributed under the terms of Creative Commons Attribution License (http://creativecommons.org/licenses/by/3.0). This permits unrestricted use, distribution, and reproduction in any medium, provided the original work is properly cited. 
Saad et al. Biochemical Compounds 2016,

http://www.hoajonline.com/journals/pdf/2052-9341-4-5.pdf

doi: $10.7243 / 2052-9341-4-5$

\section{Introduction}

Misfolding and self aggregation of a specific group of proteins in physiological systems have been linked to various human disorders and diseases [1,2]. Of particular interest and importance is the protein human transthyretin (hTTR) (also known as prealbumin) which has major implication in Familal Amyloidotic Polyneuropathy (FAP) and associated conditions $[3,5]$. hTTR is mainly synthesized in the liver and brain's choroid plexus region. It is then secreted and circulated in the plasma as a soluble protein $[6,7]$. FAP comprises a family of inherited amyloidosis affecting the peripheral nerves and this is caused by deposition of highly neurotoxic insoluble self-aggregated hTTR and this can often be fatal $[8,9]$. Our understanding of this disease and associated hTTR aggregation is now slowly beginning to emerge following extensive research in the field $[10,11]$. hTTR is known to exist in various genetic mutant forms. In fact accumulated research has established that mutations in hTTR can be linked to aggregation state and pathogenesis of FAP [12-16]. For example among others hTTR variants with $\mathrm{Val}^{30}$ Met and Ser ${ }^{52}$ Pro mutations became of high interest because of their potential implications in FAP $[15,16]$. Pathogenic mutated TTR proteins form fibril like aggregates more efficiently than the nonpathogenic and usually non-mutated TTR. The deposition of these aggregates in different tissues including central nervous system leads to FAP as well as Systemic Senile Amyloidosis (SSA) [17], Amyloidotic Cardiomyopathy (AC) [18] and Carpal Tunnel Syndrome [19].

It was further established that calcium influx in neurons mediated by TTR via specific calcium and voltage-gated sodium channels can be regulated depending on the nature of mutation in TTR and this remains an important contributing factor in pathogenic stage of FAP [20]. Interestingly this type of calcium dysregulation is also associated with other neurodegenerative diseases involving amyloidosis that include Alzheimer's disease [21]. Recently various biochemical and histological studies in cells and tissues suggested that the aggregation and fibril formation of hTTR are dependent not only on the types of mutation but also more importantly on its proteolytic cleavage. This cleavage leads to a C-terminally truncated hTTR fragment which has been found to aggregate far more efficiently than the full length or uncleaved physiological form $[22,23]$. Such molecular events involving proteolytic truncation favouring subsequent aggregation have been noted for human tau and alpha synuclein proteins which have been linked to Alzheimer's and Parkinson's diseases respectively $[\mathbf{2 4 , 2 5}$. It is important to point out that these and other amyloid proteins do not bear any amino acid sequence homology. However they all possess a high content of beta sheet structure and propensity to form fibrillary structures. The overall secondary structure of the protein promotes the formation of aggregated protein that is responsible for neurotoxicity [26].

hTTR is a $60 \mathrm{kDa}$ extracellular protein which is composed of 4 identical subunits of $15 \mathrm{kDa}$ size. It is synthesized in the liver and brain and its gene is located in chromosome number 18 .
As a soluble protein it circulates in the blood where it binds with thyroid hormone thyroxine T4 and Retinol Binding ProteinVitamin A complex and mediates their transport. It is also present in lower amount in cerebrospinal fluid as a major carrier of thyroxine hormone $[\mathbf{2 7}, \mathbf{2 8}]$. hTTR mediated FAP is an inherited autosomal dominant disease which has no global boundary. It mostly affects older population age higher than 60 years. The disease exhibits variable clinical symptoms the most common of which are acute heat sensation, painful paresthesias leading to autonomic dysfunction [17]. In recent years hTTR has also been described as an enzyme with matrix metallo protease activity $[29,30]$. Several substrates of hTTR have been reported among which the most important is Apo-1A protein [31].

Despite many functional activities, the aggregation of hTTR and its pathogenesis associated with amyloidosis remain as the major focus of hTTR research. So far the detailed molecular mechanism leading to hTTR aggregation is still not completely understood although significant progress has been made in this regard. Thus recent studies confirmed that C-terminally truncated hTTR produced by proteolysis undergoes selfaggregation much more rapidly and efficiently than the full length mature hTTR and this occurs in a fibrillary and amyloidogenic pathway leading to neurotoxicity. The site for this cleavage has recently been proposed as between Lys ${ }^{48}$ and $T h r^{49}$ but the protease responsible has not yet been identified although it was proposed to be a member of trypsin family. Moreover structural studies revealed that recombinant hTTR protein lacking the first 50 amino acids (from residue 21-71) exhibit an unfolded sheet-like structure unlike the full length mature protein which may explain its rapid self-aggregation compared to the full length protein [32]. Interestingly recombinant hTTR protein lacking the first 37 amino acids (residue 21-57) exhibits a folded structure like the full length protein and showed much less propensity for self-aggregation [32].

A more recent study revealed that for both wild type and variant hTTR, a significantly high level of hTTR (49-127) fragment was found to be present in ex vivo fibril aggregates along with only a small quantity of full length proteins [33]. Moreover the above hTTR sequence domain has also been reported to be the major constitutent of wild type and hTTR variants derived amyloid fibrils linked to cardiomyopathy [34]. Based on enzyme digestion study of recombinant and variant hTTR proteins it is further proposed that proteolytic cleavage of hTTR and its variants at Lys ${ }^{48} \downarrow \mathrm{Thr}^{49}$ leading to the formation of C-terminal fragment (49-127) may be a crucial event in hTTR aggregation and associated pathogenesis. The presence of high levels of this fragment aggregate in the amyloid deposit supports this conviction. So far the enzyme responsible for this cleavage has not yet been identified although it is predicted to be a trypsin like enzyme. The proposed biosynthesis of mature hTTR protein from its precursor including its proteolysis leading to enhanced aggregation is shown schematically in Figure 1.

The objective of this study is to confirm using model peptides that hTTR is cleaved by a trypsin-like enzyme at the carboxy 


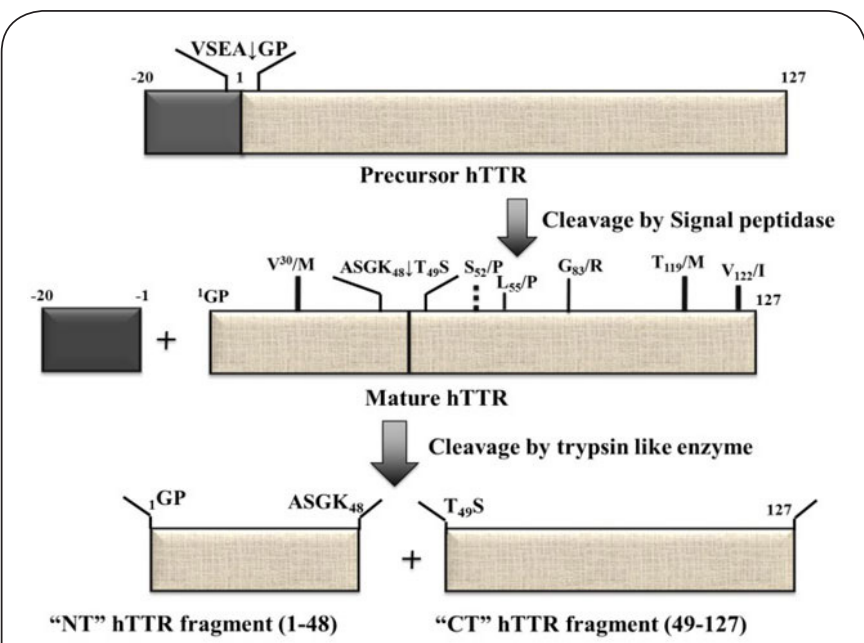

Figure 1. Schematic diagram showing the biosynthesis of mature hTTR protein and its various structural domains. The figure also highlights some of the the key natural mutation sites with either pathological or non-pathological consequence as well as the proposed proteolytic cleavage site indicated by a vertical arrow with the amino acid sequence. NT: N-terminal; CT: C-terminal. The mutations are indicated in vertical solid and dotted lines. The dotted line mutation is known to cause rapid aggregation of hTTR and high degree of pathogenic amyloidosis. The solid thick line mutations are known to cause less aggregation.

terminus of Lys residue as indicated by a vertical arrow in the sequence Ala-Ser-Gly-Lys ${ }^{48} \downarrow$ Thr $^{49}$-Ser-Glu-Ser and that this cleavage can be prevented by a trypsin-inhibitor. The other goal is to study the functional consequence of those key hTTR mutations that are located in close proximity of the cleavage site and are associated with severe pathogenic amyloidosis. The study on the role of hTTR mutation is challenging and complex due the discovery of at least 100 different point mutations in hTTR with severe to mild or no implications to amyloidosis [http://amyloidosismutations.com/attr.html]. A significant number of these mutations have effects on hTTR aggregation and associated pathogenesis [34]. However, only a selected number of mutations in hTTR have been strongly linked to high pathogenic severity of amyloidosis. It is suggested that such mutations in hTTR lead to instability of its tetrameric structure which ultimately fold apart as monomer that then self-aggregates into fibril structures promoted by its proteolysis $[32,33]$. It is now well established that pathogenic severity depends on $\mathrm{hTTR}$ aggregation rate and it is most aggressive for the rare $\mathrm{L}^{55} \mathrm{P}$ mutation compared to the more common $\mathrm{V}^{30} \mathrm{M}$ mutation [35]. A number of these mutations are depicted in Figure 1. Lately considerable interest has developed on $\mathrm{S}^{52} \mathrm{P}$ mutation that is considered as physiologically most relevant for increased hTTR aggregation and pathogenesis [33]. The effect of this mutation on hTTR proteolysis is also investigated in this study using synthetic peptides and the result was compared with those from wild type and other mutant hTTR peptides. As part of this study we also intend to examine whether trypsin activity essential for hTTR cleavage can be regulated by polyhydroxy compounds like glucose and heparin similar to those observed with di- and tri-hydroxy organic solvents eg diethylene glycol and glycerol $[36,37]$.

\section{Materials and methods}

All Fmoc amino terminal protected amino acids (L-configuration) with an additional side chain protection as needed, peptide coupling agents like $\mathrm{N}, \mathrm{N}, \mathrm{N}^{\prime}, \mathrm{N}^{\prime}$-Tetramethyl-O- $(1 \mathrm{H}-$ benzotriazol-1-yl) uronium hexafluorophosphate (HBTU), Diisipropyl ethyl amine (DIEA),Poly Amino Linker Polyethylene Glycol Polystyrene (PAL-PEG-PS) resin for peptide synthesis, organic solvents such as Acetontrile (ACN, HPLC grade); Dimethyl sulphoxide (DMSO, analytical grade) and Dimethyl formamide (DMF, analytical grade) were obtained from Bachem Inc (Torrance, Ca, USA), Calbiochem Novabiochem Inc, (San Diego, Ca, USA), Sigma-Aldrich Chemical Company (Milwaukee, WI, USA), Neosystems Inc, (Strasbourg, France) and PE-Biosystems (Foster City, Ca, USA). Trifluoroacetic acid (TFA, analytical grade) and all reagents such as Phenol, TriIsopropyl Silane (TIS) and Ethane Dithiol (EDT) constituting Reagent $B$ [36] for peptide deprotection and its cleavage from bound resin were purchased from Aldrich-Sigma Chemical (Milwaukee, WI, USA). Matrix Assisted Laser Desorption Ionization (MALDI) and Surface Enhanced Laser Desorption Ionization (SELDI) time of flight (tof) mass spectra (MS) were recorded using Voyager (Model: DE-pro, Bench top, Applied (previously PerSeptive) Biosystems, Framingham, Ma, USA) and Ciphergen Protein Chips (Fremont, Ca, USA) instruments respectively. The mass spectra plates namely the re-usable gold plates for SELDI and stainless steel plates for MALDI were obtained from respective companies. 1-Cyano 4-Hydroxy Cinnamic acid (CHCA) or 2,5 Di-Hydroxy Benzoic acid (DHB) (Sigma-Aldrich Chemical Company) were used as energy absorbing matrices. The enzyme rrecombinant bovine trypsin (Mol Wt $23.3 \mathrm{kDa}$ ) and its fluorogenic substrate Boc-Glu-AlaArg-MCA, and Boc-Arg-Val-Arg-Arg-MCA (MCA: 4 Methyl 7 Coumarinamide) required for in vitro trypsin assay were bought from Sigma-Aldrich Company.

\section{Peptide synthesis}

All peptides derived from hTTR sequence (Table 1), each 20 amino acids long were synthesized on an automated solidphase peptide synthesizer instrument (Intavis, Multipep model, Germany) using Fmoc (Fluorenyl methoxy carbonyl) mediated chemistry and HBTU in presence of DIEA as coupling reagent [21]. The following amino acid side chain protecting groups were used, tBu (tertiary butyl) for Ser, Thr and Glu residues; Trityl (triphenyl methyl) for His and Boc (t-butyloxy carbonyl) for Lys. The synthesis started from carboxy (C-) to amino terminus( $\mathrm{N}-$-) end on an unloaded Fmoc-protected tentagel [a PAL-PEG \{poly amino linker poly ethylene glycol\} cross linked to PS (polystyrene)] resin. Following completion of 
Saad et al. Biochemical Compounds 2016,

http://www.hoajonline.com/journals/pdf/2052-9341-4-5.pdf

doi: $10.7243 / 2052-9341-4-5$

Table 1. List of various peptides derived from hTTR protein sequence encompassing the proposed protease cleavage site and a few key mutations. Each peptide is $\mathbf{2 0}$ amino acids long.

\begin{tabular}{|c|c|c|c|}
\hline $\begin{array}{l}\text { Peptide } \\
\text { Name }\end{array}$ & $\begin{array}{l}\text { Amino acid se- } \\
\text { quence }\end{array}$ & $\begin{array}{l}\text { Calculated } \\
\text { MW, Da }\end{array}$ & $\begin{array}{l}\text { Observed } \\
\text { MW, Da }\end{array}$ \\
\hline P1:hTTR ${ }^{41-60}$ & $\begin{array}{l}\text { WEPFASGK }{ }^{48} \downarrow \\
\text { TSESGELHGLTT }\end{array}$ & $2,134.29$ & $\begin{array}{l}2,133.4 \\
(\mathrm{M}+\mathrm{H})^{+}\end{array}$ \\
\hline $\begin{array}{l}\text { P2:hTTR }{ }^{41-60} \\
\text { S }^{52} / \mathrm{P}\end{array}$ & $\begin{array}{l}\text { WEPFASGK }{ }^{48} \downarrow \\
\text { TSEPGELHGLTT }\end{array}$ & $2,144.33$ & $\begin{array}{l}2,143.6 \\
(\mathrm{M}+\mathrm{H})^{+}\end{array}$ \\
\hline $\begin{array}{l}\text { P3:hTTR }{ }^{41-60} \\
\mathrm{~K}^{48} / \mathrm{A}\end{array}$ & $\begin{array}{l}\text { WEPFASG }{ }^{48} \downarrow \\
\text { TSESGELHGLTT }\end{array}$ & $2,076.95$ & $\begin{array}{l}2,075.9 \\
(\mathrm{M}+\mathrm{H})^{+}\end{array}$ \\
\hline $\begin{array}{l}\text { P4:hTTR }{ }^{41-60} \\
\mathrm{~T}^{49} / \mathrm{A}\end{array}$ & $\begin{array}{l}\text { WEPFASGK }^{48} \downarrow \\
\text { ASESGELHGLTT }\end{array}$ & $2,104.26$ & $\begin{array}{l}2,104.1 \\
(\mathrm{M}+\mathrm{H})^{+}\end{array}$ \\
\hline
\end{tabular}

Da:Dalton; MW: Molecular weight; $\downarrow$ : Proposed cleavage site. The mutated amino acid residues are indicated in bold underlined characters.

synthesis, peptides were cleaved off from the resin and fully deprotected at the same time by treatment with Reagent B consisting of $88 \%$ TFA, $5 \%$ phenol, $5 \%$ water and $2 \%$ TIS $[36,37]$ for $3 \mathrm{~h}$ at ambient temperature. The crude peptides thus obtained were purified by Reverse Phase High Performance Layer Chromatography (RP-HPLC) as described later and fully characterized by SELDI and MALDI Mass Spectrometer using CHCA or DHB as an energy absorbing matrix [38].

\section{Peptide purificationby RP-HPLC}

All crude peptides were purified by RP-HPLC using $C_{18}$ Silica gel analytical column (Varian, $10 \times 25 \mathrm{~cm}$ column size). During RP-HPLC purification, peptides were separated using a linear gradient of Solvent B from $10 \%$ to $90 \%$ in Solvent $A$ [Solvent $B=0.1 \%$ TFA in $A C N$ and Solvent $A=0.1 \%$ TFA in water]. Fractions were collected and analyzed as the elution was monitored on-line by photodiode array (PDA) detector with wavelength fixed at 214, 230, 260 and $280 \mathrm{~nm}$. Peaks were collected and lyophilized twice to a white fluffy powder. It was then subjected to analysis by mass spectrometry for their identifications as described in [39].

\section{SELDI-tof-mass spectrometry}

SELDI-tof mass spectrum was performed on re-usable clean gold plate chips with $2 \mu \mathrm{l}$ of sample and $2 \mu \mathrm{l}$ of CHCA or DHB matrix solution as described earlier $[38,39]$. Each mass spectrum was calibrated against pure commercial ACTH (1-17) peptide (MW 2,093.71 Da), purchased from Sigma-Aldrich Company) both as an internal and external standard.

\section{Trypsin assay}

The protease activity of commercial trypsin was measured using the fluorogenic substrate Boc-Arg-Val-Arg-Arg-MCA or Boc-Glu-Ala-Arg-MCA (100 $\mu \mathrm{M}$ final concentration). Typically 5 $\mu$ l of freshly prepared trypsin solution $(0.1 \mathrm{mg} / \mathrm{ml}$ in water) was incubated with peptidyl fluorogenic substrate in an aqueous buffer consisting of $25 \mathrm{mM}$ Tris $+25 \mathrm{mM}$ Mes, pH 7.4 and the fluorescence released at various times was measured with a fluorometer instrument with excitation and emission wavelengths fixed at 370 and $460 \mathrm{~nm}$ respectively. The experiment was conducted in a 96-microtitre well plate (black color, 50 $\mu \mathrm{l}$ volume capacity) using fluorescence spectrophotometer (Molecular Devices Co, USA) [38,39].

\section{Trypsin inhibition by DMF: $\mathrm{K}_{\mathrm{i}}$ determination}

This was performed by initial rate and stop-time assays at $37^{\circ} \mathrm{C}$ in $50 \mu \mathrm{L}$ final volume in a 96-well plate (Dynetac) in a buffer solution of $25 \mathrm{mM}$ Tris $+25 \mathrm{mM}$ Mes, $\mathrm{pH}$ 7.4. The experiment was performed with three substrate (Boc-RVRR-MCA) concentrations of $25 \mu \mathrm{M}, 50 \mu \mathrm{M}$, and $100 \mu \mathrm{M}, 1 \mathrm{mg} / \mathrm{mL}$ trypsin and varying amounts of DMF ranging from 0-30 $\mu \mathrm{L}$ and buffer. The release of fluorescence was monitored by a spectrofluorometer (Spectramax, Gemini XS) at excitation and emission wavelengths of $360 \mathrm{~nm}$ and $470 \mathrm{~nm}$ respectively. The $K_{\mathrm{i}}$ (inhibition constant) was derived from Cornish-Bowden plot using the protocol published earlier $[39,40]$.

\section{Peptide digestion study \\ hTTR peptide digestion with trypsin \\ Absence of trypsin inhibitor}

hTTR(41-60) peptide $(10 \mu \mathrm{g})$ was dissolved in water $(1 \mu \mathrm{l})$, then diluted with buffer $25 \mathrm{mM}$ Tris + 25mM MES, pH 7.4 (30 $\mu \mathrm{l})$, and digested with trypsin $(10 \mu \mathrm{l}, 1 \mathrm{mg} / \mathrm{mL})$ with shaking (60rpm) at $37^{\circ} \mathrm{C}$. The reaction was monitored at various times ranging from $0 \mathrm{~min}-3$ hour, depending on the nature of the peptide used, by extracting $10 \mu \mathrm{l}$ of the reaction aliquot and terminating the reaction by adding $2 \mu$ of glacial acetic acid. This procedure was also followed for the digestion of other peptides, namely the mutants: $\mathrm{S}^{52} / \mathrm{P}, \mathrm{K}^{48} / \mathrm{A}$, and $\mathrm{T}^{49} / \mathrm{A}$ (Table 1 ). Each aliquot was analyzed by RP-HPLC for the cleavage efficiency. Peaks were collected, lyophilized, and characterized by SELDI-tof mass spectroscopy.

\section{Presence of trypsin inhibitor (DMF)}

Each peptide digestion with trypsin was monitored in the absence and presence of a trypsin-specific inhibitor, namely DMF, reported for the first time in this paper. The protocol used is the same as indicated above, except that along with the control digestion, we have included two additional digestion experiments using the inhibitor at two different concentrations, one considered as low and the other as high. The blockage of the cleavage in the presence of the inhibitor was assessed by RP-HPLC chromatograms as discussed earlier.

\section{3-D molecular modeling study}

3D molecular model structures of all synthetic hTTR peptides as well as the full length protein molecule including the mutants were generated by using algorithms based on Hyperchem $v$ 11.0 software program (Hypercube Inc). Theoretical energy minimised geometry in vacuo was used following PolakRibiere energy minimisation algorithm $[39,40]$. The presence 
Saad et al. Biochemical Compounds 2016,

of potential $\mathrm{H}$-bonds were assessed and were displayed in dotted lines in the model figure.

\section{Statistical analysis}

Unless otherwise indicated, results were compared using Student's $t$ test. A p value of less than 0.05 was considered significant. Each experiment was performed in triplicates and the data were used for statistical purposes.

\section{Results}

\section{Peptide design}

hTTR monomeric protein bio-synthesised in the physiological system as a 147 amino acid long precursor protein $(-20$ to 127 ) (Calculated MW: $15,887 \mathrm{Da}$ ) which following cleavage by signal peptidase generates the mature monomeric chain of 127 amino acids long (1-127 residues) (Calculated MW: $13,761 \mathrm{Da}$ ). For numbering of amino acid sequence in all hTTR protein and its peptides we follow the above common system based on 127 amino acids long mature hTTR protein. The biosynthesis, the various structural domains, cleavage sites and a few selected key mutations in hTTR are shown schematically in Figure 1. The above single monomeric chain forms a strong tetrameric complex (Calculated MW $\sim 55,044 \mathrm{Da}$ ) that exhibits its physiological and biological activity [33-35]. A recent study with hTTR wild type as well as its key physiological mutant variants suggested that each monomeric form of hTTR is proteolytically cleaved likely by a trypsin like enzyme and this site may be located not far from 50 amino acids from the $\mathrm{N}$-terminal end. This conclusion is derived from the findings that (i) an N-terminally 50 amino acids truncated $\mathrm{hTTR}$ recombinant protein aggregates at a much faster kinetic rate than the full length hTTR protein and (ii) in contrast an N-terminally 37 amino acids truncated recombinant $\mathrm{hTTR}$ protein aggregates almost at the same rate as the recombinant full length hTTR [27]. A more recent study identified this cleavage site as between Lys ${ }^{48}$ and $\mathrm{Thr}^{49}$ [33].

In order to confirm this we designed a peptide encompassing this cleavage site covering 20 amino acids (from residue 41-60 of mature hTTR sequence) with 10 amino acids on either side of the proposed cleavage site. Along with this wild type peptide we also designed two additional peptides which contain the physiologically relevant mutations $\mathrm{Ser}^{52} / \mathrm{Pro}$ and $\mathrm{Thr}^{49} / \mathrm{Ala}$. The rationale for this is based on the published observation that implicated the first mutation (Ser ${ }^{52} / \mathrm{Pro}$ ) to most pathogenic state of amyloidosis followed by the second mutation (Thr ${ }^{49} / \mathrm{Ala}$ ) $[33,35]$. A fourth peptide containing Lys ${ }^{48} /$ Ala mutation has also been designed in order to examine the importance of basic Lys ${ }^{48}$ residue in hTTR proteolysis. All peptides with their molecular weights and amino acid sequences are listed in Table 1.

\section{Peptide synthesis and characterization}

All hTTR peptides with carboxy terminal in amide form, were successfully synthesized by Fmoc based solid phase chemistry, purified by RP-HPLC and fully characterized by SELDI tof mass spectrometry [39-41].

Thus the SELDI tof mass spectra of purified peptides P1, P2, P3 and P4 as displayed in Figure 2 exhibited intense peaks at $\mathrm{m} / \mathrm{z} 2,133.4,2,143.6,2,075.9$ and 2,104.1 Da respectively which are in excellent agreement with the corresponding calculated values (Table 1). As expected each peptide also exhibited in its mass spectrum an additional peak at $[\mathrm{M}+\mathrm{Na}$ (23 Da)] for example the peak at $\mathrm{m} / \mathrm{z} 2,098$ for peptide P3 (Figure 2). The mass spectral data thus confirmed the identity of each peptide and its purity since there was only one major molecular ion peak with a few minor additional peaks as impurities in their mass spectra.
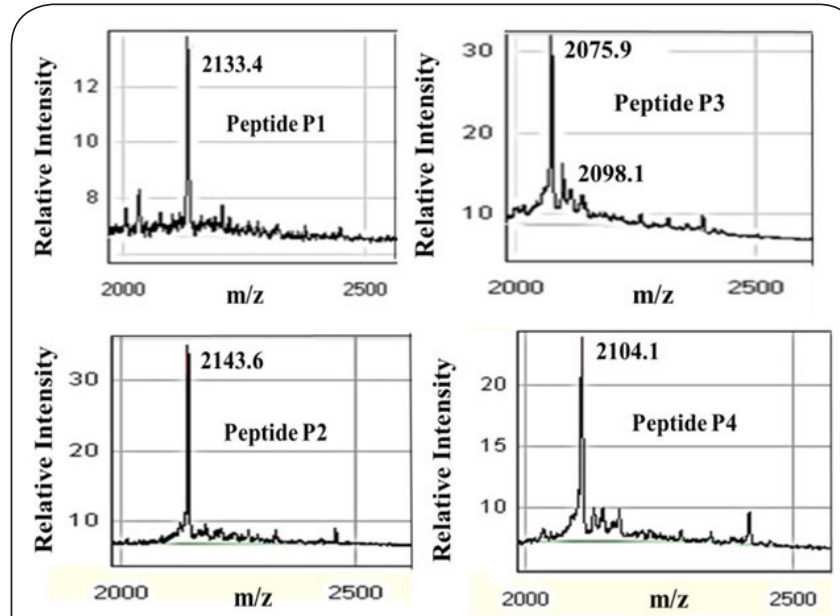

Figure 2. SELDI-Tof mass spectra of all designed synthetic hTTR peptides as indicated in the figure. The observed molecular masses were found to be in good correlation with those of calculated values. m/z: Mass/Charge ratio.

\section{Trypsin assay and its inhibition}

Trypsin activity was determined by in vitro assay using BocRVRR-MCA substrate by both progress curve or on line and stop time or end point reading methods. While working with various low-volatile water miscible organic solvents we surprisingly noted that the solvent $\mathrm{N}, \mathrm{N}^{\prime}$-Dimethyl formamide (DMF) exhibits a modest protease inhibitory activity towards trypsin. This is demonstrated in Figures $3 \mathrm{~A}$ and $\mathbf{3 B}$ which showed a gradual decrease in trypsin activity (both on line progress curve and stop time data) following incubation with increasing amounts of DMF. To our knowledge this is the first clear demonstration of trypsin inhibition by DMF which is well known for its high polarity and dissolving property for materials that are not soluble in aqueous system. Previously there were reports of protease activity stabilisation of subtilisin enzyme by a mixture of aqueous organic solvent containing DMF as much as $70 \%$ [42]. Regulatory effect of organic solvents that includes DMF on the activity of another enzyme thermolysin has also been reported [43]. Based on our current observation we 

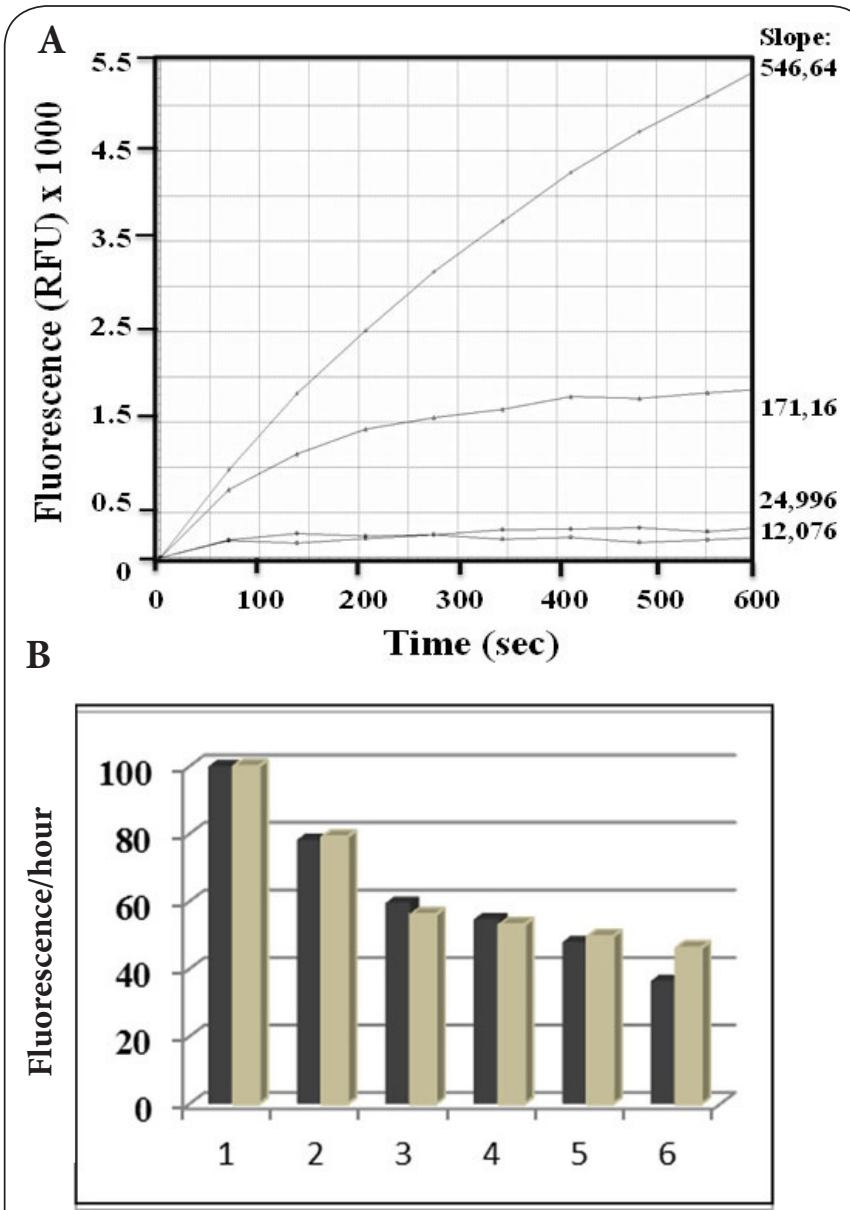

DMF $(\mu \mathrm{l})$

Figure 3. (A) Trypsin inhibition by NN'-Dimethyl formamide (DMF) at various concentrations using progress curves against the fluorogenic substrate Boc-RVRR-MCA. RFU: Raw Fluorescence Unit.

(B) Trypsin inhibition by NN'-Dimethyl formamide (DMF) at various concentrations using stop time or end time data against the fluorogenic substrate Boc-RVRR-MCA. Data averaged from two separate experiments each in triplicate are shown.

decided to use DMF as trypsin inhibitor in the present study instead of more commonly used trypsin inhibitors such as SBTI (Soybean Trypsin Inhibitor) [44] or PMSF (Phenyl Methyl Sulfonyl Fluoride) [45].

\section{$\mathrm{K}_{\mathrm{i}}$ determination}

The inhibitory action of DMF towards trypsin was further investigated by Cornish-Bowden plot using three different concentrations (1000, 500 and $250 \mu \mathrm{M}$ ) of the fluorogenic substrate Boc-RVRR-MCA $[39,40]$. The data is presented in Figure 4. As shown in the figure the three lines pass through a common intersection point suggesting a competitive inhibition of trypsin by DMF. The $\mathrm{K}_{\mathrm{i}}$ value based on the intersection of curves $1 \& 2$, curves $2 \& 3$ and curves $1 \& 3$ are respectively 129.75 , 127.08 and $123.67 \mu \mathrm{M}$. Thus based on these the measured

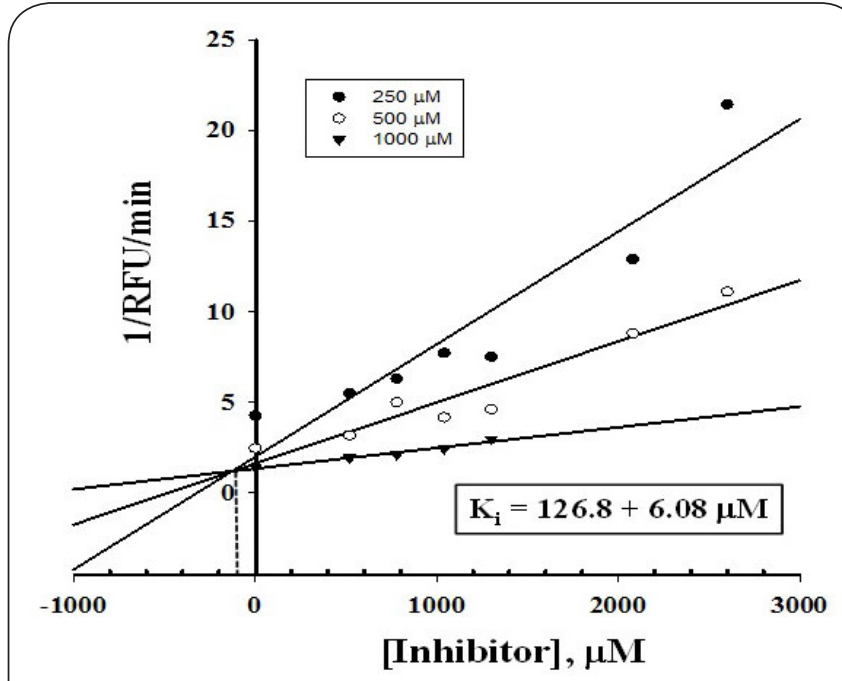

Figure 4. Determination of inhibition constant (Ki) value for inhibition of Trypsin by N,N'-Dimethyl Formamide against the fluorogenic substrate Boc-RVRR-MCA. Figure shows the Cornish-Bowden plot for three different substrate concentrations as indicated. Ki was calculated for each pair of curves and the final average value is indicated in the figure. RFW/min: Raw Fluorescence Unit (arbitrary) released per minute.

average $K_{i}$ value for inhibition of trypsin-mediated cleavage of Boc-RVRR-MCA by DMF is $126.8 \pm 6.08 \mu \mathrm{M}$.

\section{Peptide digestion by trypsin}

Each hTTR peptide was examined for its cleavage by commercial trypsin and the rates of their clea ages were determinted by RP-HPLC chromatograms and co pared under identical conditions. Figure 5 shows the RP-HPLC chromatograms of crude digest of wild type hTTR peptide P1 ${ }^{44}$ WEPFASGK $\downarrow$ TSESGELHGLTT ${ }^{60}$ ] following incubation with trypsin for 7 $\mathrm{min}$. Besides the peak for the undigested peptide eluting at Rt: 31 min as confirmed by its mass spectrum (calculated $\mathrm{MW}=2,134.29 \mathrm{Da}$, observed 2,133.4 Da), the chromatogram shows two additional peaks eluting at Rt: $23.8 \mathrm{~min}$ and 28.7 min which were found to be more intense in 25 min digest RP-HPLC chromatogram (Not shown). The SELDI-tof mass spectra of materials corresponding to these HPLC peaks showed strong peaks at $\mathrm{m} / \mathrm{z}$ 1,230.5 Da and $921.0 \mathrm{Da}$ respectively which are consistent with the calculated masses of the C-terminal fragment (TSESGELHGLTT, calculated $\mathrm{MW}=1,231.58 \mathrm{Da}$ ) and $\mathrm{N}$-terminal fragment (WEPFASGK, calculated MW=921.44 Da). These results confirmed cleavage of peptide $\mathrm{P} 1$ by trypsin at $\mathrm{K} \downarrow T$ site which became more significant (>90\%) after 25 minutes of digestion (See later). The cleavage of peptide P1 bytryps in was further investigated in a time dependent manner ranging from $30 \mathrm{sec}$ to $60 \mathrm{~min}$. The results are shown in Figure 6 where the RP-HPLC chromatograms of crude digest at various times were overlaid in a stacking format for better visualization purpose. The data showed the formation of in- 
Saad et al. Biochemical Compounds 2016,

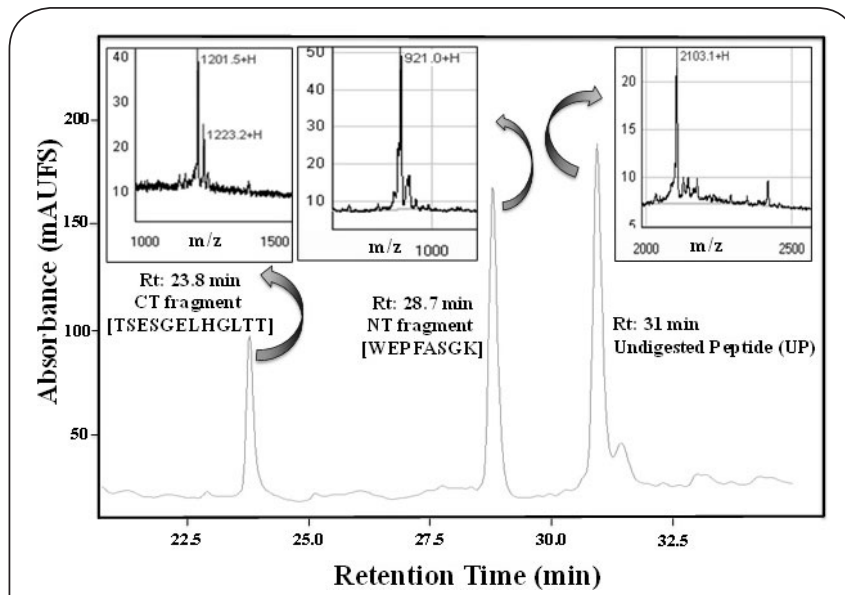

Figure 5. RP-HPLC chromatogram of crude trypsin digest of hTTR peptide $\mathrm{P} 1$ over a period of $7 \mathrm{~min}$. The figure also displays the SELDI tof mass spectra of all the collected peaks. m/z: Mass/Charge; CT: Carboxy Terminal; NT: N or Amino Terminal; Rt: Retention time; mAUFS: Milli Absorbance Full Scale.

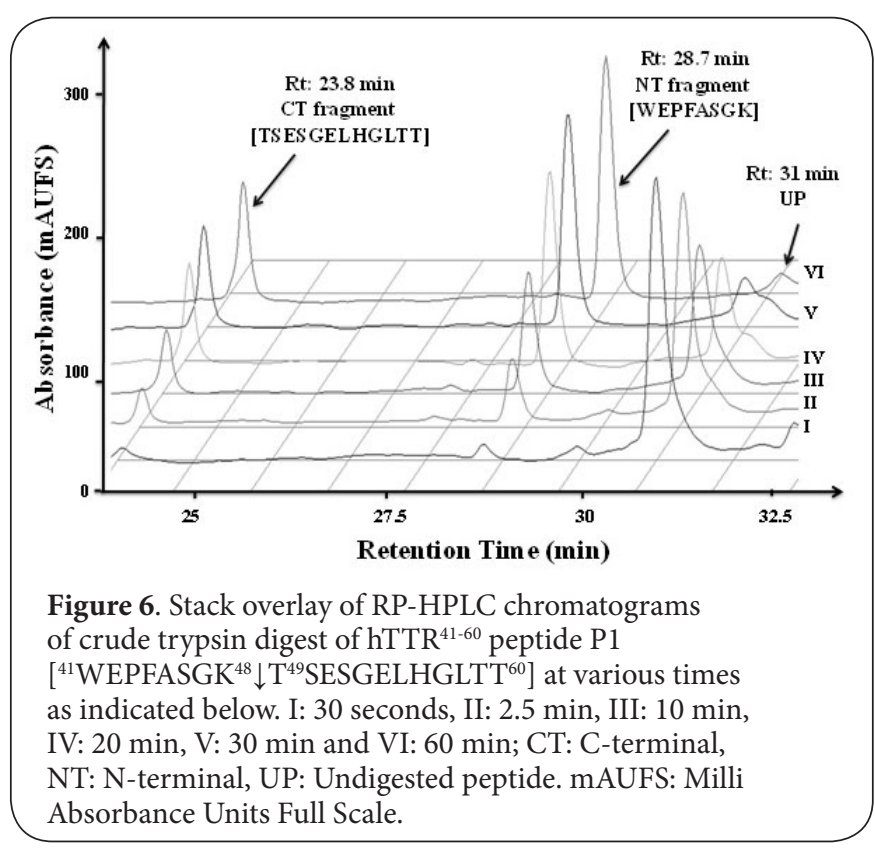

creasing amounts of fragment peaks at Rt 23.8 and 28.7 mins with the time of digestion. Additionally our data also revealed that both mutant peptides P2 and P4 were also cleaved by trypsin at the same $\mathrm{K} \downarrow T$ site in a differential manner. Thus we noted that peptide $\mathrm{P} 2$ was cleaved far more efficiently than control wild type peptide P1 while peptide P4 was cleaved a lot less efficiently compared to that of control wild type peptide P1. A similar time dependent cleavage study of peptide $\mathrm{P} 2$ by trypsin was also performed and the results are displayed in Figure 7. The measured half life time or time for $50 \%$ cleavage of each peptide under identical condition

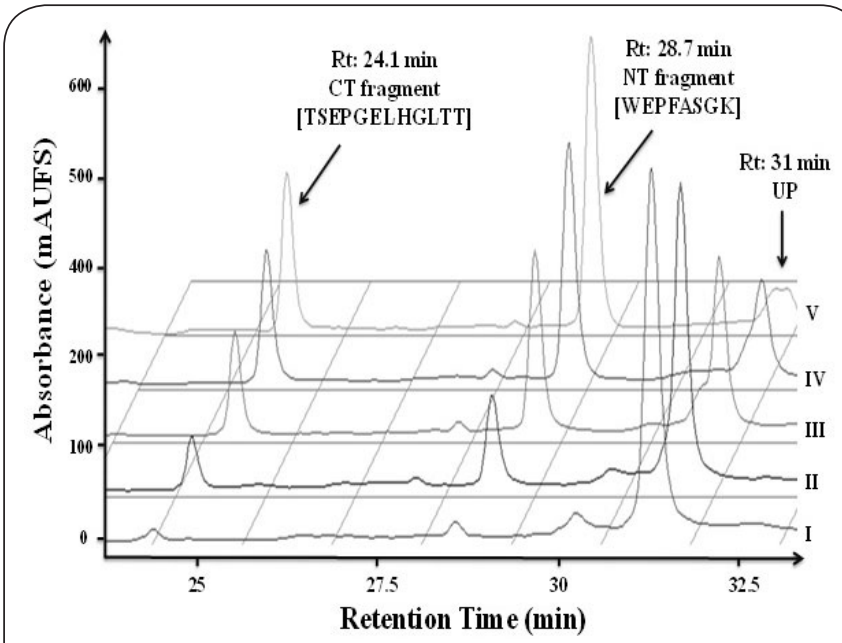

Figure 7. Stack overlay of RP-HPLC chromatograms of trypsin digest of hTTR ${ }^{41-60} \mathrm{~S}^{52} / \mathrm{P}$ mutant peptide P2 $\left[{ }^{41}\right.$ WEPFASGK ${ }^{48} \downarrow$ TSEP $^{52}$ GELHGLTT $\left.{ }^{60}\right]$ peptide at various times as indicated here. I: 30 seconds, II: 45 seconds, III: 1 min, IV: 5 min, V: 10 min CT: C-terminal, NT: N-terminal, UP: Undigested peptide, mAUFS: Milli Absorbance Units Full Scale.

is measured and the results are shown in Table 2. The data revealed that under identical digestion condition, $\mathrm{S}^{52} / \mathrm{P}$ mutant peptide $\mathrm{P} 2$ is cleaved by $\sim 7.5$ fold more efficiently than wild type control peptide $\mathrm{P} 1$. The remaining peptide $\mathrm{P} 3$ was found to be completely uncleaved by trypsin even after 60 min of digestion time.

\section{Inhibition of peptide cleavage}

In order to investigate whether the cleavage of hTTR peptides by trypsin as noted above can be blocked by a trypsin inhibitor, we incubated peptide $\mathrm{P} 1$ in the absence and presence of excess trypsin inhibitor DMF $(100 \mu \mathrm{M})$ under identical condition. The results are shown in Figure $\mathbf{8}$ which confirmed that DMF (100 $\mu$ M concentration) which inhibited trypsin mediated

Table 2. List of measured half cleavage times of various hTTR peptides following digestion with trypsin in the absence and presence of trypsin inhibitor (only for peptide P1) (For details see Materials Methods section). DMF, an inhibitor of trypsin shown in this study, was used in this experiment.

\begin{tabular}{lll}
\hline Peptide & $\mathbf{T}_{1 / 2}(\mathbf{m i n})$ & Relative fold $\mathbf{T}_{1 / 2}$ \\
\hline P1 & $7.4+0.99$ & 7.5 \\
P2 & $0.985+0.098$ & 1 \\
P3 & $\mathrm{NC}$ & $\mathrm{ND}$ \\
P4 & $\sim 10 \%$ Cleavage in $60 \mathrm{~min}$ & $\mathrm{ND}$ \\
P1 + Inhibitor & $76.6+0.97$ & 77.8 \\
\hline
\end{tabular}

NA: Not Applicable; NC: No cleavage; ND: Not determined, $\mathrm{T}_{1 / 2}$ : Half or $50 \%$ cleavage time 
Saad et al. Biochemical Compounds 2016,

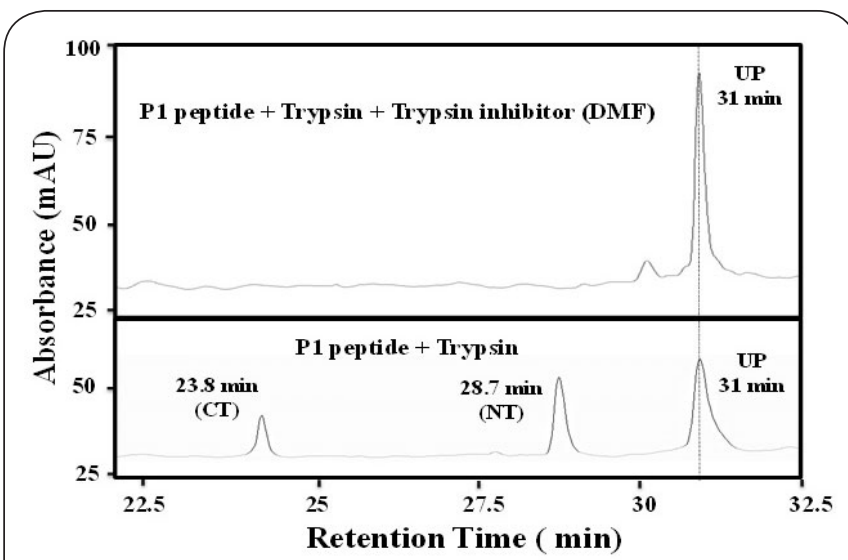

Figure 8. RP-HPLC chromatograms showing the blockade of trypsin mediated cleavage of hTTR peptide P1 $\left[{ }^{41}\right.$ WEPFASGK ${ }^{48} \downarrow$ TSESGELHGLTT $\left.{ }^{60}\right]$ by NN'-dimethyl formamide $(100 \mu \mathrm{M})$. Bottom panel shows the RP-HPLC chromatogram of the peptide digest for 7 minute period. It shows three peaks for the undigested peptide (UP), the C-terminal (CT) and N-terminal (NT) cleaved fragments. The top panel shows the RP-HPLC chromatogram of the same digest in the presence of DMF. It shows only one peak corresponding to the undigested peptide confirming the complete inhibition of cleavage by DMF.

cleavage of peptidyl fluorogenic substrate Boc-RVRR-MCA can also block almost completely the trypsin mediated cleavage of peptide P1at post Lys residue. Similarly we also observed that DMF can block trypsin mediated cleavage of mutant peptides P2 and P4 under similar condition (data not shown). These results support the previous observation that hTTR and its mutants are proteolytically cleaved by trypsin like enzyme and therefore this cleavage may likely be regulated by inhibitor of trypsin [33].

\section{Regulator of trypsin activity and effect on hTTR cleavage} Various studies in the past have reported that polyhydroxy organic solvents such as ethylene glycol, isopropanol or glycerine can stabilize the protease activity of various enzymes in an effective manner [43]. As a result such solvents mixed with aqueous buffer have been routinely used in the past to store proteases in active form at low temperature where it does not freeze. Upto $50 \%$ of such organic solvents in aqueous medium have been used for this purpose. Based on this observation we became interested to examine whether trypsin activity can be regulated by the presence higher molecular weight polyhydroxy compounds such as glucose, heparin and glycerine. trypsin $(10 \mu \mathrm{l}$, concentration $0.1 \mathrm{mg} / \mathrm{ml}$ or $\sim 0.043 \mathrm{nmol}$ ) was incubated separately for $10 \mathrm{~min}$ at room temperature with aqueous solution of each of these substances at various molar ratios (1:1, 1:10 and 1:100) and the solutions were then lypholised. Each lyophilized powder was then re-dissolved in water and immediately tested for its activity in comparison to a control sample of trypsin which was not incubated with any hydroxylic compound. Trypsin activity was then measured using peptidyl fluorogenic substrate (done in triplicates). A representative data is shown in Figures $9 \mathrm{~A}$ and $\mathbf{9 B}$ displaying trypsin regulatory activity of heparin at various molar ratios.

Our data so far indicated that glycerine helps to maintain the enzyme activity and act as a stabilizer and not a regulator. Glucose on the other hand down regulates trypsin activity almost in a dose-dependent manner. A maximum of $20 \%$ inhibition was noted with 1:100 molar ratio treated sample. In contrast heparin treated trypsin exhibited a modest increase in
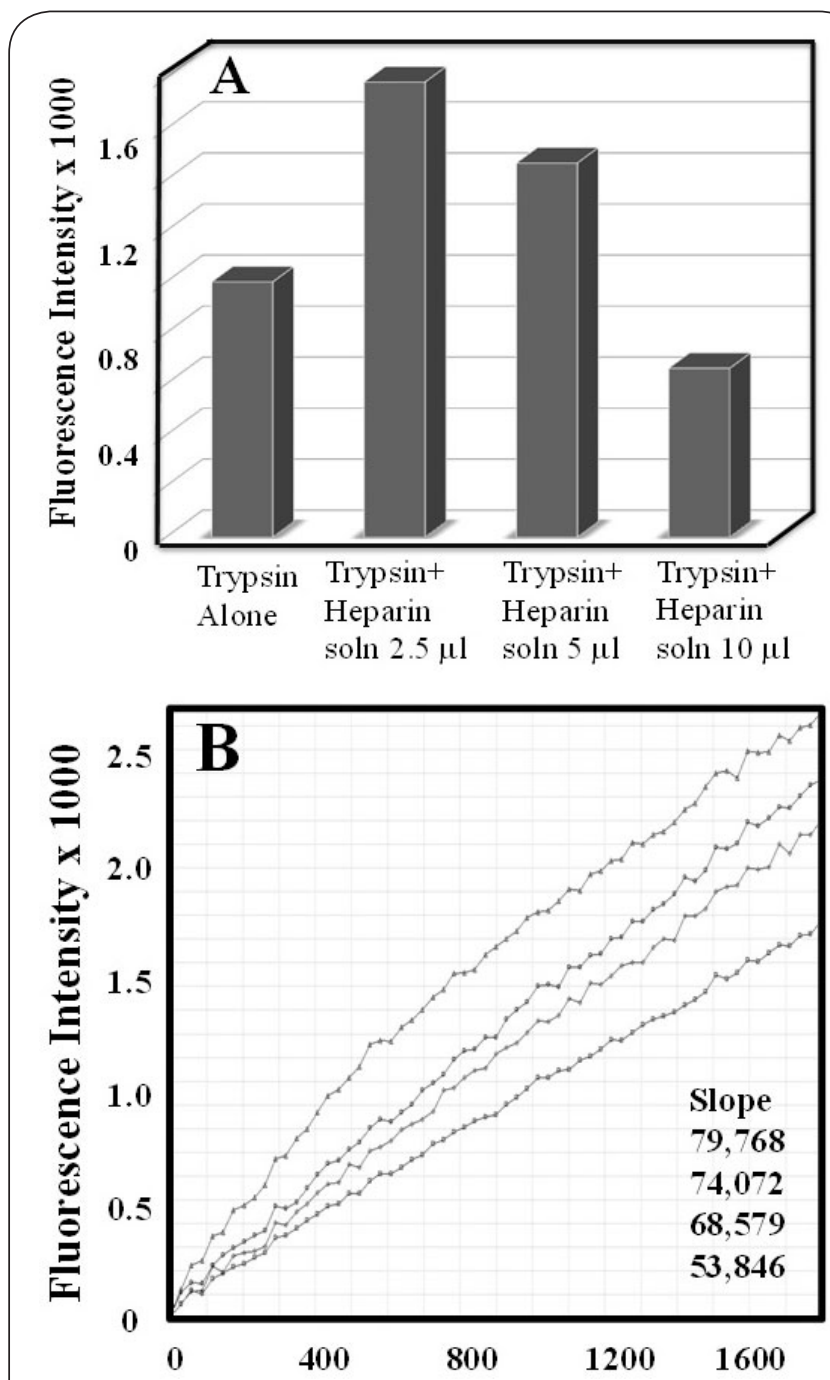

Figure 9. Protease activity of trypsin following incubation with heparin at various concentrations using the fluorogenic substrate Boc-RVRR-MCA $(100 \mu \mathrm{M})$. (A) Bar graph showing the end point fluorescence readings and (B) Progress curves showing slopes for lines in the order from top to the bottom in the absence and presence of heparin solution ( $1 \mathrm{mM})$ in various amounts as indicated. From top: Trypsin $+2.5 \mu \mathrm{l}$ heparin solution; Trypsin $+5 \mu$ l heparin solution; Control Trypsin alone and Trypsin $+10 \mu \mathrm{l}$ heparin solution. Slope values are in arbitrary units. 
activity compared to control under similar condition, displaying a maximum of $30 \%$ enhanced protease activity against the fluorogenic peptide. This is demonstrated by both stop time and on line or progress curve assays as shown in Figures 9A and 9B. Similar observations were also noted when hTTR peptides P1 and P2 were incubated in parallel with glucose and heparin treated trypsin samples and the results were compared to that with control untreated trypsin. Thus heparin treated trypsin cleaved both peptides $\mathrm{P} 1$ and $\mathrm{P} 2$ nearly 25 $30 \%$ more efficiently than regular trypsin (Data not shown). Previous studies reported enzyme regulatory activity of both heparin and glucose towards several proteolytic enzymes mostly of serine protease family which includes trypsin [46-48].

\section{3-D model study of hTTR peptides}

All synthetic $h T_{T R}^{41-60}$ peptides namely the wild type $\mathrm{P} 1$, along with the mutant peptides $\mathrm{S}^{52} / \mathrm{P}(\mathrm{P} 2), \mathrm{K}^{48} / \mathrm{A}(\mathrm{P} 3)$ and $\mathrm{T}^{49} / \mathrm{A}(\mathrm{P} 4)$ (Table 1) were analysed based on their 3-D in vacuo generated energy minimised model structures. These structures were obtained by Hyperchem software professional program (v 11.0. Hypercube Company, USA) using the Polak-Ribiere geometry minimisation algorithm and all possible $\mathrm{H}$-bonds were computed $[39,41]$. Similarly, a much longer $\mathrm{hTTR}^{10-90}$ polypeptide as well as its $\mathrm{S}^{52} / \mathrm{P}, \mathrm{K}^{48} / \mathrm{A}$, and $\mathrm{T}^{49} / \mathrm{A}$ variants were also subjected to structural analysis using their energy minimised 3D structures generated in a similar manner. The size of this polypeptide was chosen such that it is relevant as much as possible to the actual conformation of the full length mature hTTR protein. The comparative analyses of structures of these polypeptides are conducted in the context of similar structure analyses on the corresponding shorter peptides. Theoretically derived 3D model structure of two key peptides namely peptide P1 and peptide $\mathrm{P} 2$ are shown in Figure 10 where all the potential $\mathrm{H}$ bonds are indicated with white dotted lines. The secondary structural conformations for the backbone of the above two peptides are displayed in Figure 11.

\section{Peptide model analysis}

Presence of $\mathrm{H}$-bonds has been detected in 3 out of 4 peptides studied. The wild type P1 peptide hTTR ${ }^{41-60}$ exhibited a distinct beta-turn structure exposing the $\mathrm{Lys}^{48}-\mathrm{Thr}^{49}$ cleavage site as shown by arrow in Figure 10. Its 3D model structure also showed the presence of a turn sheet structure followed by short helix like structure in the backbone (Figure 11). In contrast the $\mathrm{S}^{52} / \mathrm{P}$ mutant peptide P2 exhibited a significantly different backbone secondary structure compared to that of peptide P1. Thus P2 peptide possesses mostly an extended linear helical structure stabilized by two strong $\mathrm{H}$-bonds involving $\mathrm{PrO}_{3}$ with $\mathrm{Ser}_{6}$ and $\mathrm{Gly}_{7}$ with $\mathrm{Ser}_{10}$. These $\mathrm{H}$-bonds may be involved in stabilizing the observed helical structure. Interestingly there is only one observed $\mathrm{H}$ (hydrogen)-bond in $\mathrm{P} 1$ peptide $\left(\mathrm{His}_{16}\right.$ is $\mathrm{H}$-bonded to $\left.\mathrm{Thr}_{20}\right)$. Despite this $\mathrm{P} 1$ peptide still assumes a non-extended backbone structure as indicated above. Thus significant structural differences have

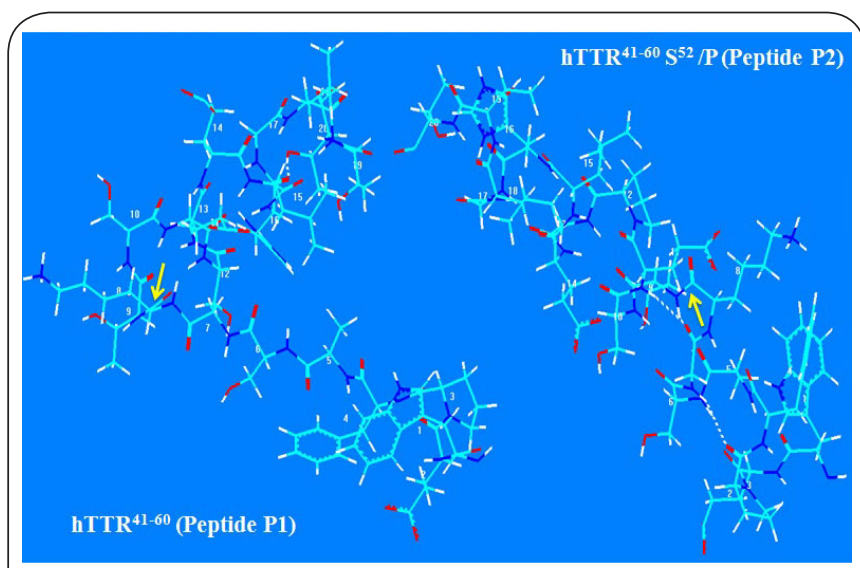

Figure 10. Comparison of energy minimized 3D model structures of wild type hTTR ${ }^{41-60}$ (Peptide P1) (Left) and its $\mathrm{S}^{52} / \mathrm{P}$ mutant (Peptide P2) (Right). The yellow arrow shows the trypsin cleavage site (Lys $\downarrow$ Thr) whereas the dotted white lines represent all the potential $\mathrm{H}$-bonds observed.

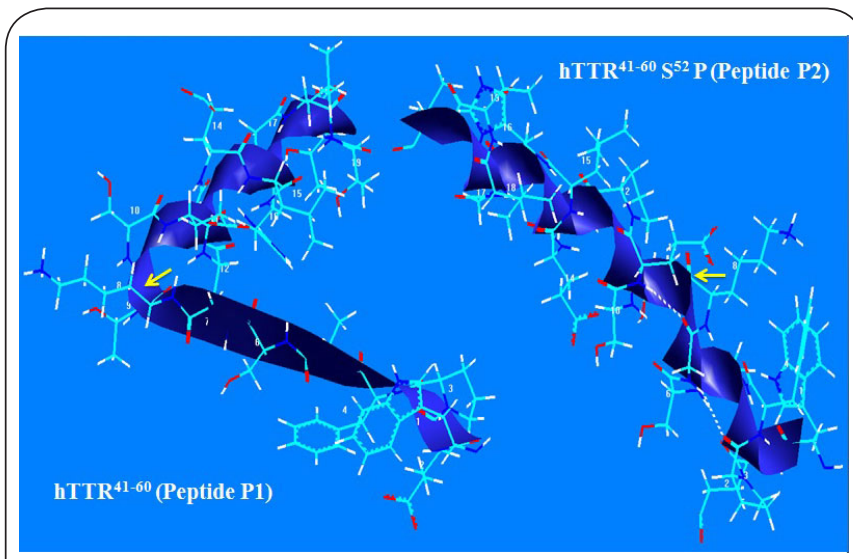

Figure 11. Comparison of energy minimized 3D model structures of wild type hTTR ${ }^{41-60}$ (Peptide P1) (Left) and its $\mathrm{S}^{52} / \mathrm{P}$ mutant (Peptide P2) (Right) showing the secondary structures of their backbones. The yellow arrow shows the trypsin cleavage site (Lys $\downarrow$ Thr) whereas the dotted white lines represent all the potential $\mathrm{H}$-bonds observed.

been noted between peptides $\mathrm{P} 1$ and $\mathrm{P} 2$. This may allow more exposure of the trypsin-cleavage site to the environement leading to an increased proteolysis. Interestingly $\mathrm{K}^{48 /} \mathrm{A}$ mutant hTTR peptide P3 which is not cleaved by trypsin showed one strong $\mathrm{H}$-bond in its structure involving $\operatorname{Trp}_{1}$ and $\mathrm{Ala}_{5}$ residues. Moreover the remaining peptide $\mathrm{hTTRT}^{49} / \mathrm{A}$ mutant which is cleaved by trypsin with least efficiency did not exhibit any $\mathrm{H}$-bond in its 3D structure. Like the short peptides, the longer hTTR polypeptide and its mutant variants also exhibited differences in their overall 3D structures, backbone secondary structures and $\mathrm{H}$-bond profiles. Thus $20 \mathrm{H}$-bonds are observed in $\mathrm{hTTR}^{10-90}$ whereas 19 such bonds are noted in $\mathrm{K}^{48} / \mathrm{A}$ mutant varient. Of these, 16 were common to both. The 4 remaining 
Saad et al. Biochemical Compounds 2016,

$\mathrm{H}$-bonds that differ in $\mathrm{hTTR}^{10-90}$ peptide are those which involve Ala ${ }^{48}$ with $\mathrm{Th}^{51}$; Asp $^{49}$ with $\mathrm{Glu}^{53}$; $\mathrm{Phe}^{75}$ with $\mathrm{Glu}^{77}$ and Gly ${ }^{78}$ with $\mathrm{Tyr}^{80}$. Instead of these the corresponding $\mathrm{K}^{48} / \mathrm{A}$ mutant exhibited the following remaining $3 \mathrm{H}$-bonds involving Asp ${ }^{49}$ with $\mathrm{Thr}^{51}$; Ser ${ }^{57}$ with Glu ${ }^{53}$ and $\mathrm{Phe}^{75}$ with $1 \mathrm{le} \mathrm{e}^{79}$. These differences may explain the structural diversity between the two. This may likely be unique to the mutation and may account for the differences in kinetics of proteolysis by trypsin. The differences in the pattern of $\mathrm{H}$-bonds were also observed between the short peptide and the corresponding long peptide. For example, $\mathrm{His}^{16}$ is $\mathrm{H}$-bonded to $\mathrm{Thr}^{20}$ in $\mathrm{hTTR}^{41-60}$ peptide but not in the long $\mathrm{hTTR}^{10-90}$ peptide. Also the $\mathrm{H}$-bond between Trp ${ }^{1}$ to Ala ${ }^{5}$ observed in short $\mathrm{K}^{48} / \mathrm{A}$ mutant peptide is not observed in the long $\mathrm{K}^{48} / \mathrm{A}$ peptide (Model figures not shown).

\section{Discussion}

\section{Peptide cleavage}

Our in vitro trypsin digestion data using designed hTTR peptides clearly confirmed that trypsin cleaves wild type peptide sequence at Lys $\downarrow$ Thr site as proposed in a recent study with full length mature recombinant wild type and variant hTTR proteins [33]. The result also demonstrated that $\mathrm{Ser}^{52}$ Pro variant peptide $\mathrm{P} 2$ is processed in a significantly faster kinetics compared to the corresponding wild type peptide P1. In fact under identical in vitro condition $\mathrm{P} 2$ is cleaved nearly 7.5 -fold faster than $\mathrm{P} 1$ as reflected by the measured $\mathrm{T}_{1 / 2}$ or $50 \%$ cleavage times (Table 2). This is also in agreement with the previous study demonstrating by gel electrophoresis that recombinant hTTR Ser ${ }^{52} /$ Pro variant protein is cleaved more efficiently in vitro by trypsin compared to the corresponding wild type hTTR protein [33]. However this study did not provide any comparative analysis of this cleavage between the two proteins. This mutation first found in British nationals is responsible for rapid progression of amyloidosis and cardiomyopathy [49]. However both studies provide rationale for the observed high pathogenenicity associated with this hTTR mutation in amyloidosis since such mutation is expected to generate an increased level of hTTR C-terminal (49-127) fragment that undergoes self-aggregation much more rapidly than the wild type full length mature hTTR protein [33].

Furthermore our data also suggested that physiologically relevant Thr ${ }^{49} /$ Ala mutant hTTR peptide P4 is processed by trypsin at an extremely slow kinetic rate under identical condition compared to wild type peptide $\mathrm{P} 1$, thereby protecting hTTR from proteolysis which is considered as a key factor for promoting aggregation leading to pathogenic form of amyloidosis [32,33]. In fact this mutation commonly observed in Italian and French nationals led to neuropathy and cardiomyopathy but with other different clinical features [50]. An important finding of our study is that the mutation of Lys ${ }^{48}$ by Ala in hTTR completely abrogates the cleavage by trypsin. Although this mutation has not yet been reported in physiological condition, it has a great implication in $\mathrm{hTTR}$ associated amyloidosis, polyneuropathy and its pathogenesis.
Such a mutation may be considered as a protector against hTTR proteolysis and possibly it's associated amyloidosis.

Our study reinforces the previous findings that the proteolysis of hTTR is mediated by a trypsin like enzyme. However the precise enzyme responsible for this cleavage is yet to be fully identified. Our study with peptides showed this enzyme is a Lys specific cleaving enzyme like endoproteinase Lys-C enzyme [51] and not necessarily a trypsin like enzyme. Although endoproteinase Lys-C enzyme has been detected largely in bacteria [52,53], a mammalian homolog of such an enzyme is yet to be characterized. However existance of such an enzyme in mammalians including human is currently hypothetical but is still a possibility. If identified such an enzyme could have enormous implication in hTTR associated pathogenesis.

Our study has established that trypsin mediated cleavage in $\mathrm{hTTR}$ peptide at Lys $\downarrow$ Thr can be efficiently blocked by $\mathrm{NN}^{\prime}$-dimethyl formamide (DMF) which is described for the first time in this study as an inhibitor of trypsin. Inhibition of trypsin by DMF has been confirmed in vitro by both on line and stop time assay against peptidyl fluorogenic substrate such as Boc-RVRR-MCA as shown in Figures $3 \mathbf{A}$ and 3B. This is further reinforced by the determination of inhibition constant $\mathrm{K}_{\mathrm{i}}$ for DMF against trypsin using Boc-RVRR-MCA. This is described as a moderate inhibitor with measured $\mathrm{K}_{\mathrm{i}} \sim 126$ $\mu \mathrm{M}$ (Figure 4). Although our finding of DMF as an inhibitor of trypsin is quite unexpected and accidental but it is not completely unrealistic since compounds containing similar functional moiety such as benzamidines, guanidines and even amides have been reported to inhibit in vitro protease activity of serine proteases like thrombin, trypsin etc $[\mathbf{5 4 , 5 5}$.

\section{Regulation of trypsin activity}

In addition to above findings our study also revealed that proteolytic activity of trypsin can not only be stabilized by adding di or tri-hydroxylic organic solvents such as glycerine but can also be up- or down-regulated particularly by adding polyhydroxy compounds such as glucose or heparin. In fact our data indicated that while addition of glucose led to a slight inhibitory effect on trypsin, in contrast addition heparin induced a modest upregulation of activity for trypsin. Such regulatory effects have been demonstrated against the cleavages of fluorogenic peptide as well as the hTTR peptides P1 and P2. Protease stabilizing activity of glycerine and similar solvents has been reported in the past in literature [42]. In fact such solvents are routinely used for preservation and storage of enzymes at low temperature for a long period of time $[36,37,42]$. In terms of sugars a few of them such as sucrose, glucose, lactose, sorbitol and heparin have been reported as enzyme and protein stabilizers. These have been shown to prevent degradation of both enzymes and proteins $[46,47]$. Recently glycerol has also been used as a stabilizer for antibodies [56]. Our demonstration of trypsin regulatory activity in vitro by the addition of glucose and heparin is interesting although such compounds have been shown to 
Saad et al. Biochemical Compounds 2016,

regulate activity of other protease family such as MMPs [57].

Lately studies revealed that hTTR itself also behaves as protease most likely of MMP type [58]. A few substrates such as Apo-E for hTTR have been identified. However the exact functional role of such proteolytic activity of hTTR in its aggregation is not yet clear. Further studies will be warranted to investigate this aspect [31].

\section{D model}

In this study we have also theoretically performed 3D structural studies of a 20 mer hTTR peptide and its 3 mutant variant peptides in vacuo. Comparison of these structures revealed that the pathologically aggressive $\mathrm{Ser}^{52}$ /Pro mutatnt hTTR peptide exhibited a widely different backbone secondary structure compared to the corresponding wild type peptide. In fact it showed a predominantly helix structure that is likely stabilized by two $\mathrm{H}$-bonds leading to more exposure and access to the Lys $\downarrow$ Thr cleavage site. On the contrary the wild type peptide showed a turn structure that is likely to be fexible as it did not exhibit any $\mathrm{H}$-bonds. These findings may provide rationale for observed rapid cleavage of $\mathrm{Ser}^{52} / \mathrm{Pro}$ mutant peptide or protein by trypsin. Another interesting observation was that Lys ${ }^{48} /$ Ala mutant variant peptide also exhibited a specific backbone structure of mixed type that is characterized by two different types of $\mathrm{H}$-bonds. This made the cleavage site completely inaccessible that may explain its resistance to proteolytic cleavage by trypsin.

\section{Conclusions}

In summary our in vitro study using designed model peptides based on hTTR sequence and its key mutant variants demonstrated that wild type hTTR peptide is indeed cleaved by trypsin at Lys ${ }^{48} \downarrow T h r^{49}$ site quite efficiently and cleanly and that this cleavage is significantly increased for $\mathrm{Ser}^{52} /$ Pro mutant peptide. This provides rationale for the observed high pathogenic amyloidosis outcome for the carrier of this particular mutation since such cleavage has been linked to rapid aggregation of hTTR fragment form. This study also showed that the above cleavage in hTTR may be mediated by a trypsin like enzyme which can be inhibited by a trypsin inhibitor or by mutation of Lys ${ }^{48}$ to Ala. However there is a high possibility that a more specific enzyme that belongs to bacterial Endoprotienase Lys-C family may play a role in this cleavage. So far such an enzyme has not yet been elucidated in mammalian systems including humans although a few have been predicted or proposed in the past. Though highly theoretical our energy minimised 3D molecular modeling study in vacuo revealed that both Lys ${ }^{48} / \mathrm{Ala}$ and $\mathrm{Ser}^{52} /$ Pro mutant peptides exhibited significantly different backbone structural conformations compared to the corresponding wild type peptide and this provided necessary support for the observed differences in their proteolytic processing rates by trypsin. This study also highlighted a potential therapeutic strategy for hTTR associated amyloidosis by targeting the Lys ${ }^{48} \downarrow T^{T h} r^{49}$ cleaving enzyme with specific inhibitors.

\section{List of abbreviations}

Aa: Amino acid

ACN: Acetonitrile

CHCA: a-Cyano 4-hydroxy cinnamic acid

Da: Dalton

DHB: 2,5 dihydroxy benzoic acid

DMF: $\mathrm{N}, \mathrm{N}$ '-Dimethyl formamide

EDT: Ethane dithiol

h: Human

HATU: 1-[Bis(dimethylamino)methylene]-1H-1,2,3-triazolo[4,5-b] pyridinium 3-oxid hexafluorophosphate

HBTU: N,N,N,N'-Tetramethyl-O-(1 H-benzotriazol-1-yl) uronium hexafluorophosphate

HOBT: 1-Hydroxy benzotriazole

kDa: Kilodalton

mAUFS: Milli Absorbance Units Full Scale

MS: Mass Spectrum

MW: Molecular weight

PAL PEG PS: Poly amino linker poly ethylene glycol poly styrene RP-HPLC: Reverse Phase High Performance Liquid/Layer Chromatography

RPM: Revolution per minute

Rt: Retention time

SELDI tof MS: Surface Enhanced Laser Desorption lonization

Time of Flight Mass Spectrometry

TFA: Trifluoro acetic acid

TCEP: Tris (2-carboxy ethyl) phosphine

TIS: Tri isopropyl silane

TTR: Transthyretin

\section{Competing interests}

The authors declare that they have no competing interests.

Authors' contributions

\begin{tabular}{|l|c|c|c|c|}
\hline Authors' contributions & MS & CL & CK & AB \\
\hline Research concept and design & -- & -- & -- & $\checkmark$ \\
\hline Collection and/or assembly of data & $\checkmark$ & $\checkmark$ & $\checkmark$ & -- \\
\hline Data analysis and interpretation & -- & $\checkmark$ & -- & -- \\
\hline Writing the article & -- & -- & -- & $\checkmark$ \\
\hline Critical revision of the article & -- & -- & -- & $\checkmark$ \\
\hline Final approval of article & -- & -- & -- & $\checkmark$ \\
\hline Statistical analysis & -- & -- & -- & -- \\
\hline
\end{tabular}

\section{Acknowledgement}

We acknowledge the support, encouragement and access to laboratory space from Prof. James Gomes, Interdisciplinary School of Health Science (ISHS), Faculty of Health Science, U Ottawa for this study. We thank Dr. Sarmistha Basak, former scientist, Ottawa Hospital Research Institute for her valuable comments and suggestions about the work. Financial support in part was provided by NSERC, Govt of Canada and UROP, University of Ottawa.

\section{Publication history}

Editors: Fong-Fu Hsu, Washington University School of Medicine, USA. Leonid Breydo, National Chiao Tung University, Taiwan.

Received: 17-May-2016 Final Revised: 28-Jul-2016

Accepted: 01-Aug-2016 Published: 16-Aug-2016 
Saad et al. Biochemical Compounds 2016,

http://www.hoajonline.com/journals/pdf/2052-9341-4-5.pdf

doi: $10.7243 / 2052-9341-4-5$

\section{References}

1. Stefani M. Protein misfolding and aggregation: new examples in medicine and biology of the dark side of the protein world. Biochim Biophys Acta. 2004; 1739:5-25. I Article I PubMed

2. Herczenik $E$ and Gebbink MF. Molecular and cellular aspects of protein misfolding and disease. FASEB J. 2008; 22:2115-33. | Article | PubMed

3. Gasperini RJ and Small DH. Neurodegeneration in familial amyloidotic polyneuropathy. Clin Exp Pharmacol Physiol. 2012; 39:680-3. | Article | PubMed

4. Ando $Y$, Nakamura M and Araki S. Transthyretin-related familial amyloidotic polyneuropathy. Arch Neurol. 2005; 62:1057-62. | Article | PubMed

5. Benson MD and Kincaid JC. The molecular biology and clinical features of amyloid neuropathy. Muscle Nerve. 2007; 36:411-23. | Article | PubMed

6. Blake CC, Geisow MJ, Oatley SJ, Rerat B and Rerat C. Structure of prealbumin: secondary, tertiary and quaternary interactions determined by Fourier refinement at 1.8 A. J Mol Biol. 1978; 121:33956. | Article | PubMed

7. Ferreira N, Pereira-Henriques A, Attar A, Klarner FG, Schrader T, Bitan G, Gales L, Saraiva MJ and Almeida MR. Molecular tweezers targeting transthyretin amyloidosis. Neurotherapeutics. 2014; 11:450-61. | Article | PubMed Abstract | PubMed FullText

8. Bhak G, Choe YJ and Paik SR. Mechanism of amyloidogenesis: nucleation-dependent fibrillation versus double-concerted fibrillation. BMB Rep. 2009; 42:541-51. | PubMed

9. Hurshman AR, White JT, Powers ET and Kelly JW. Transthyretin aggregation under partially denaturing conditions is a downhill polymerization. Biochemistry. 2004; 43:7365-81. | Article | PubMed

10. Saelices L, Johnson LM, Liang WY, Sawaya MR, Cascio D, Ruchala $P$, Whitelegge J, Jiang L, Riek R and Eisenberg DS. Uncovering the Mechanism of Aggregation of Human Transthyretin. J Biol Chem. 2015; 290:28932-43. | Article | PubMed Abstract | PubMed FullText

11. Saraiva MJ, Birken S, Costa PP and Goodman DS. Amyloid fibril protein in familial amyloidotic polyneuropathy, Portuguese type. Definition of molecular abnormality in transthyretin (prealbumin). J Clin Invest. 1984; 74:104-19. | Article | PubMed Abstract | PubMed FullText

12. Connors LH, Richardson AM, Theberge R and Costello CE. Tabulation of transthyretin (TTR) variants as of 1/1/2000. Amyloid. 2000; 7:54-69. | Article | PubMed

13. Carr AS, Pelayo-Negro AL, Evans MR, Laura M, Blake J, Stancanelli C, lodice V, Wechalekar AD, Whelan CJ, Gillmore JD, Hawkins PN and Reilly MM. A study of the neuropathy associated with transthyretin amyloidosis (ATTR) in the UK. J Neurol Neurosurg Psychiatry. 2016; 87:620-7. | Article | PubMed

14. Meng LC, Lyu H, Zhang W, Liu J, Wang ZX and Yuan Y. Hereditary Transthyretin Amyloidosis in Eight Chinese Families. Chin Med J (Engl). 2015; 128:2902-5. | Article | PubMed Abstract | PubMed FullText

15. Pont L, Benavente F, Vilaseca M, Gimenez E and Sanz-Nebot V. Characterisation of serum transthyretin by electrospray ionisationion mobility mass spectrometry: Application to familial amyloidotic polyneuropathy type I (FAP-I). Talanta. 2015; 144:1216-24. | Article | PubMed

16. Gonzalez-Duarte A, Lem-Carrillo M and Cardenas-Soto K. Description of transthyretin S50A, S52P and G47A mutations in familial amyloidosis polyneuropathy. Amyloid. 2013; 20:221-5. | Article | PubMed

17. Pinney JH, Whelan CJ, Petrie A, Dungu J, Banypersad SM, Sattianayagam P, Wechalekar A, Gibbs SD, Venner CP, Wassef N, McCarthy CA, Gilbertson JA, Rowczenio D, Hawkins PN, Gillmore JD and Lachmann HJ. Senile systemic amyloidosis: clinical features at presentation and outcome. J Am Heart Assoc. 2013; 2:e000098. | Article | PubMed Abstract | PubMed FullText

18. Patel KS and Hawkins PN. Cardiac amyloidosis: where are we today? J Intern Med. 2015; 278:126-44. | Article | PubMed

19. Tojo K, Tsuchiya-Suzuki A, Sekijima Y, Morita H, Sumita N and Ikeda S. Upper limb neuropathy such as carpal tunnel syndrome as an initial manifestation of ATTR Val30Met familial amyloid polyneuropathy. Amyloid. 2010; 17:32-5. | Article | PubMed

20. Hou X, Parkington HC, Coleman HA, Mechler A, Martin LL, Aguilar MI and Small DH. Transthyretin oligomers induce calcium influx via voltagegated calcium channels. J Neurochem. 2007; 100:446-57. | Article | PubMed

21. Brawek B and Garaschuk O. Network-wide dysregulation of calcium homeostasis in Alzheimer's disease. Cell Tissue Res. 2014; 357:427-38. | Article I PubMed

22. Liz MA, Mar FM, Franquinho F and Sousa MM. Aboard transthyretin: From transport to cleavage. IUBMB Life. 2010; 62:429-35. | Article | PubMed

23. Mizuguchi M, Hayashi A, Takeuchi M, Dobashi M, Mori Y, Shinoda H, Aizawa T, Demura $\mathrm{M}$ and Kawano K. Unfolding and aggregation of transthyretin by the truncation of $\mathbf{5 0} \mathrm{N}$-terminal amino acids. Proteins. 2008; 72:261-9. | Article I PubMed

24. Gamblin TC, Chen F, Zambrano A, Abraha A, Lagalwar S, Guillozet AL, Lu M, Fu Y, Garcia-Sierra F, LaPointe N, Miller R, Berry RW, Binder LI and Cryns VL. Caspase cleavage of tau: linking amyloid and neurofibrillary tangles in Alzheimer's disease. Proc Natl Acad Sci U S A. 2003; 100:10032-7. | Article | PubMed Abstract | PubMed FullText

25. Cullen V, Lindfors $M, N g$ J, Paetau A, Swinton E, Kolodziej P, Boston H, Saftig P, Woulfe J, Feany MB, Myllykangas L, Schlossmacher MG and Tyynela J. Cathepsin D expression level affects alpha-synuclein processing, aggregation, and toxicity in vivo. Mol Brain. 2009; 2:5. Article | PubMed Abstract | PubMed FullText

26. Khare SD and Dokholyan NV. Molecular mechanisms of polypeptide aggregation in human diseases. Curr Protein Pept Sci. 2007; 8:573-9. Article | PubMed

27. Vieira M and Saraiva MJ. Transthyretin: a multifaceted protein. Biomol Concepts. 2014; 5:45-54. | Article | PubMed

28. Gasperini RJ, Klaver DW, Hou X, Aguilar MI and Small DH. Mechanisms of transthyretin aggregation and toxicity. Subcell Biochem. 2012; 65:21124. | Article | PubMed

29. Liz MA, Leite SC, Juliano L, Saraiva MJ, Damas AM, Bur D and Sousa $\mathrm{MM}$. Transthyretin is a metallopeptidase with an inducible active site. Biochem J. 2012; 443:769-78. | Article | PubMed

30. Liz MA, Faro CJ, Saraiva MJ and Sousa MM. Transthyretin, a new cryptic protease. J Biol Chem. 2004; 279:21431-8. | Article | PubMed

31. Liz MA, Fleming CE, Nunes AF, Almeida MR, Mar FM, Choe Y, Craik CS, Powers JC, Bogyo M and Sousa MM. Substrate specificity of transthyretin: identification of natural substrates in the nervous system. Biochem J. 2009; 419:467-74. | Article | PubMed Abstract | PubMed FullText

32. Ihse E, Stangou AJ, Heaton ND, O'Grady J, Ybo A, Hellman U, Edvinsson A and Westermark P. Proportion between wild-type and mutant protein in truncated compared to full-length ATTR: an analysis on transplanted transthyretin T60A amyloidosis patients. Biochem Biophys Res Commun. 2009; 379:846-50. | Article | PubMed

33. Mangione PP, Porcari R, Gillmore JD, Pucci P, Monti M, Porcari M, Giorgetti S, Marchese L, Raimondi S, Serpell LC, Chen W, Relini A, Marcoux J, Clatworthy IR, Taylor GW, Tennent GA, Robinson CV, Hawkins PN, Stoppini M, Wood SP, Pepys MB and Bellotti V. Proteolytic cleavage of Ser52Pro variant transthyretin triggers its amyloid fibrillogenesis. Proc Natl Acad Sci U S A. 2014; 111:1539-44. | Article I PubMed Abstract I PubMed FullText

34. Bergstrom J, Gustavsson A, Hellman U, Sletten K, Murphy CL, Weiss DT, Solomon A, Olofsson BO and Westermark P. Amyloid deposits in transthyretin-derived amyloidosis: cleaved transthyretin is associated with distinct amyloid morphology. J Pathol. 2005; 206:224-32. | Article I PubMed

35. Saraiva MJ. Transthyretin mutations in health and disease. Hum Mutat. 1995; 5:191-6. | Article | PubMed

36. Castro GR. Enzymatic activities of proteases dissolved in organic solvents. Enzyme \& Microbial Technology. 1999; 23:689-94.

37. Ruiz DM and De Castro RE. Effect of organic solvents on the activity and 
stability of an extracellular protease secreted by the haloalkaliphilic archaeon Natrialba magadii. J Ind Microbiol Biotechnol. 2007; 34:111-5. | Article | PubMed

38. Palmer-Smith $\mathrm{H}$ and Basak $\mathrm{A}$. Regulatory effects of peptides from the pro and catalytic domains of proprotein convertase subtilisin/kexin 9 (PCSK9) on low-density lipoprotein receptor (LDL-R). Curr Med Chem. 2010; 17:2168-82. | Article | PubMed

39. Basak $A$ and Lotfipour F. Modulating furin activity with designed miniPDX peptides: synthesis and in vitro kinetic evaluation. FEBS Lett. 2005; 579:4813-21. | Article | PubMed

40. Basak A, Goswami M, Rajkumar A, Mitra T, Majumdar S, O'Reilly P, Bdour HM and Trudeau VL. Enediynyl peptides and iso-coumarinyl methyl sulfones as inhibitors of proprotein convertases PCSK8/SKI-1/S1P and PCSK4/PC4: Design, synthesis and biological evaluations. Bioorg Med Chem Lett. 2015; 25:2225-37. | Article | PubMed

41. Alghamdi RH, O'Reilly P, Lu C, Gomes J, Lagace TA and Basak A. LDL-R promoting activity of peptides derived from human PCSK9 catalytic domain (153-421): design, synthesis and biochemical evaluation. Eur J Med Chem. 2015; 92:890-907. | Article | PubMed

42. Bacheva AV, Filippova IY, Lysogorskaya EN and Oksenoit ES. Stability and catalytic properties of subtilisin in acetonitrile/dimethylformamide mixtures with low water content. J Mol Catalysis B: Enzymatic. 2000; 11:89-96.

43. Pazhang M, Khajeh K, Ranjbar B and Hosseinkhani S. Effects of watermiscible solvents and polyhydroxy compounds on the structure and enzymatic activity of thermolysin. J Biotechnol. 2006; 127:45-53. | Article I PubMed

44. Flavin DF. The effects of soybean trypsin inhibitors on the pancreas of animals and man: a review. Vet Hum Toxicol. 1982; 24:25-8. I PubMed

45. Turini P, Kurooka S, Steer M, Corbascio AN and Singer TP. The action of phenylmethylsulfonyl fluoride on human acetylcholinesterase, chymotyrpsin and trypsin. J Pharmacol Exp Ther. 1969; 167:98-104. I Article I PubMed

46. Back $N$ and Steger R. Effect of heparin on the kinin-forming activity of trypsin, plasmin, and various kallikreins. Proc Soc Exp Biol Med. 1970; 133:740-3. I PubMed

47. Jean E, Sealey JE, Gerten JN, Ledingham JG and Laragh JH. $48^{\text {th }}$ Annual Meeting of The Endocrine Society, Chicago. 1966. | Article

48. Rafay AM, Homer KA and Beighton D. Effect of mucin and glucose on proteolytic and glycosidic activities of Streptococcus oralis. J Med Microbiol. 1996; 44:409-17. | Article | PubMed

49. Stangou AJ, Hawkins PN, Heaton ND, Rela M, Monaghan M, Nihoyannopoulos P, O'Grady J, Pepys MB and Williams R. Progressive cardiac amyloidosis following liver transplantation for familial amyloid polyneuropathy: implications for amyloid fibrillogenesis. Transplantation. 1998; 66:229-33. | Article | PubMed

50. Almeida MR, Ferlini A, Forabosco A, Gawinowicz M, Costa PP, Salvi F, Plasmati R, Tassinari CA, Altland $K$ and Saraiva MJ. Two transthyretin variants (TTR Ala-49 and TTR Gln-89) in two Sicilian kindreds with hereditary amyloidosis. Hum Mutat. 1992; 1:211-5. | Article | PubMed

51. Elliott BW, Jr. and Cohen C. Isolation and characterization of a lysinespecific protease from Pseudomonas aeruginosa. J Biol Chem. 1986; 261:11259-65. | Article | PubMed

52. Jekel PA, Weijer WJ and Beintema JJ. Use of endoproteinase Lys-C from Lysobacter enzymogenes in protein sequence analysis. Anal Biochem. 1983; 134:347-54. I PubMed

53. Pike R, McGraw W, Potempa J and Travis J. Lysine- and arginine-specific proteinases from Porphyromonas gingivalis. Isolation, characterization, and evidence for the existence of complexes with hemagglutinins. J Biol Chem. 1994; 269:406-11. | Article | PubMed

54. Magalhaes A, Monteiro MR, Magalhaes HP, Mares-Guia M and Rogana $E$. Thrombin-like enzyme from Lachesis muta muta venom: isolation and topographical analysis of its active site structure by means of the binding of amidines and guanidines as competitive inhibitors. Toxicon. 1997; 35:1549-59. | Article | PubMed

55. Baker BR and Erickson EH. Irreversible enzyme inhibitors. CXLIV.
Proteolytic enzymes. VII. Additonal active-site-directed irreversible inhibitors of trypsin derived from $\mathrm{m}$ - and $\mathrm{p}$-(phenoxyalkoxy) benzamidines with a terminal sulfonyl fluoride. J Med Chem. 1969; 12:112-7. I PubMed

56. Vagenende $\mathrm{V}$, Yap MG and Trout BL. Mechanisms of protein stabilization and prevention of protein aggregation by glycerol. Biochemistry. 2009; 48:11084-96. | Article | PubMed

57. Caenazzo C, Garbisa S, Onisto M, Zampieri M, Baggio B and Gambaro G. Effect of glucose and heparin on mesangial alpha 1(IV)COLL and MMP2/TIMP-2 mRNA expression. Nephrol Dial Transplant. 1997; 12:443-8. I Article I PubMed

58. Gouvea IE, Kondo MY, Assis DM, Alves FM, Liz MA, Juliano MA and Juliano L. Studies on the peptidase activity of transthyretin (TTR). Biochimie. 2013; 95:215-23. | Article | PubMed

\section{Citation:}

Saad M, Lu C, Koya C and Basak A. Proteolytic truncation of human transthyretin linked to amyloidosis is mediated by a trypsin like enzyme: In vitro demonstration using model peptides. Bio Chem Comp. 2016; 4:5.

http://dx.doi.org/10.7243/2052-9341-4-5 